\title{
Pemodelan Kondisi Jaringan Listrik PT. PLN (Persero) Area Surabaya Selatan dengan Analisis Regresi Logistik Ordinal
}

\author{
Denis Olivia Siswandari dan Haryono \\ Departemen Statistika, Fakultas MIPA, Institut Teknologi Sepuluh Nopember (ITS) \\ e-mail: haryono@statistika.its.ac.id
}

\begin{abstract}
Abstrak - PT. PLN Area Surabaya Selatan merupakan salah satu unit yang mempunyai tugas pokok mendistribusikan tenaga listrik ke pelanggan. Dalam sistem tegangan listrik tentu tidak terhindar dari suatu masalah kualitas yang dibuktikan dengan adanya keluhan terhadap gangguan listrik dari masyarakat. PT. PLN (Persero) menetapkan kondisi jaringan yang teribagi menjadi 4, yaitu sempurna, sehat, sakit dan kronis. Kondisi jaringan yang ditetapkan PT. PLN selama ini masih belum tepat karena hanya berdasar pada jumlah gangguan. Tujuan dalam penelitian ini adalah mengelompokkan jaringan dengan analisis klaster K-Means dan memodelkan masing-masing kelompok jaringan PT. PLN area Surabaya Selatan dengan analisis regresi logistik ordinal, sehingga dapat diketahui variabel yang membedakan antar kelompok. Variabel prediktor dalam penelitian ini adalah kelas aset, jumlah pelanggan TM, jumlah pelanggan TR, panjang JTM, dan beban rata-rata. Data dibagi menjadi dua kelompok, yang kemudian dilakukan analisis regresi logistik ordinal pada masing masing kelompok. Variabel yang menjadi pembeda antara kelompok 1 dan kelompok 2 adalah variabel panjang JTM.
\end{abstract}

Kata Kunci-Jaringan, Klaster K-Means, PT. PLN Area Surabaya Selatan, Regresi Logistik Ordinal.

\section{PENDAHULUAN}

L ISTRIK merupakan kebutuhan yang mendasar untuk berbagai aktivitas manusia, yang menjadikan manusia tergantung akan keberadaannya. PT. PLN (Persero) merupakan Badan Usaha Milik Negara (BUMN) penyedia listrik yang memasok kebutuhan listrik untuk rumah tangga dan industri dengan jumlah pelanggan sebanyak 13,1 juta [1]. PT. PLN Area Surabaya Selatan merupakan salah satu unit PT. PLN (Persero) yang mendistribusikan tenaga listrik ke pelanggan melalui jaringan tegangan menengah, serta melayani dan menyalurkan energi kepada pelanggan. PT. PLN Area Surabaya Selatan memiliki 5 Rayon tersebar yaitu Darmo Permai, Dukuh Kupang, Rungkut, Ngagel, dan Gedangan dengan total jaringan sebanyak 157. Dalam sistem tegangan listrik tentu tidak terhindar dari suatu masalah kualitas tegangan maupun kontinuitas pelayanan. Hal ini terbukti dengan adanya keluhan terhadap gangguan listrik dari masyarakat.

Setiap tahunnya PT. PLN Area Surabaya Selatan memiliki target gangguan listrik maksimal, yang harapannya banyak gangguan listrik berada dibawah target. Untuk mencapai target tersebut, diperlukan strategi untuk efisiensi penanganan gangguan. Berdasarkan hal tersebut PT. PLN (Persero) telah menetapkan kondisi jaringan yang dibagi menjadi 4 , yaitu sempurna, sehat, sakit dan kronis. Semakin tinggi kondisi jaringan, maka semakin banyak anggaran yang diberikan. Kondisi jaringan yang telah ditetapkan PT. PLN selama ini masih belum tepat, karena hanya berdasar banyaknya gangguan di masing-masing jaringan. Padahal ada indikatorindikator lain yang diduga berpengaruh untuk menentukan kondisi jaringan seperti kelas aset, jumlah pelanggan TM, jumlah pelanggan TR, panjang JTM, serta beban rata-rata pada suatu jaringan.

Sebagai bentuk evaluasi, dalam penelitian ini akan dilakukan analisis terhadap variabel-variabel yang menentukan klasifikasi kondisi jaringan. Penelitian dilakukan dengan mengelompokkan jaringan menjadi 2 kelompok berdasarkan indikator-indikator yang diduga dapat menentukan kondisi jaringan. Kemudian dilakukan analisis regresi logistik ordinal untuk mengetahui indikator- indikator yang menjadi pembeda antar kelompok. Tujuan dari penelitian ini adalah mengelompokkan jaringan dan memodelkan masing-masing kelompok prioritas jaringan PT. PLN area Surabaya Selatan dengan analisis regresi logistik ordinal, sehingga dapat diketahui variabel yang membedakan antar kelompok.

\section{TINJAUAN PUSTAKA}

\section{A. Metode Klaster Non-Hirarki (K-Means)}

$\mathrm{K}$-means merupakan metode klaster non hirarki yang mempartisi dan membagi data ke dalam bentuk satu atau lebih kelompok, sehingga data yang memiliki karakteristik dikelompokkan ke dalam satu klaster. Teknik pengelompokan dengan menggunakan metode non hirarki adalah dirancang untuk item kelompok, bukan variabel, menjadi sebuah kelompok K-klaster. Jumlah K-klaster dapat ditentukan secara langsung atau ditentukan dengan tahap-tahap yang sesuai dengan prosedur klaster. Mac Queen menyarankan bahwa penggunaan metode $\mathrm{K}$-means untuk menjelaskan algoritma dalam penentuan suatu obyek ke dalam klaster tertentu berdasarkan rataan tertentu. Langkah analisis dengan menggunakan metode klaster non hirarki adalah sebagai berikut [2]:

1. Bagi data dalam $\mathrm{K}$ kelompok klaster

2. Tentukan pusat awal klaster.

3. Hitung jarak data ke pusat klaster dan mengelompokkan data berdasarkan mean terdekat.

4. Hitung kembali titik pusat klaster baru berdasarkan ratarata dari masing-masing $\mathrm{K}$ kelompok klaster yang terbentuk. 
5. Ulangi langkah 3 . hingga tidak ada data yang mengalami perpindahan objek atau mengalami perpindahan kelompok klaster sebelumnya..

\section{B. Pengecekan Asumsi Multikolinearitas}

Multikolinearitas merupakan terjadinya korelasi linear yang tinggi di antara variabel-variabel prediktor $\left(\mathrm{X}_{1}, \mathrm{X}_{2}, \ldots, \mathrm{X}_{\mathrm{p}}\right)$ [3]. Asumsi ini merupakan satu-satunya asumsi yang harus terpenuhi dalam menggunakan metode regresi logistik. Pengecekan asumsi multikolineraritas dapat dilakukan dengan melihat nilai VIF dari setiap variabel prediktor yang diperoleh dengan melakukan regresi masing-masing variabel prediksi dengan variabel prediktor lainnya dan melihat nilai $R^{2}$ (koefisien determinasi). Apabila nilai VIF lebih dari 10, artinya terjadi multikolinearitas antar variabel prediktor. VIF disefinisikan dalam persamaan

$$
V I F=\frac{1}{1-R_{j}^{2}}, j=1,2, . ., p
$$

dimana, $R_{j}^{2}$ adalah nilai koefisien determinasi prediktor ke-j dengan prediktor lainnya. Nilai $R_{j}^{2}$ diperoleh dari persamaan berikut:

$$
R_{j}^{2}=\frac{\sum_{i=1}^{n}\left(\hat{x}_{j i}-\bar{x}_{j}\right)^{2}}{\sum_{i=1}^{n}\left(x_{j i}-\bar{x}_{j}\right)^{2}}
$$

\section{Regresi Logistik Ordinal}

Regresi logistik ordinal merupakan salah satu metode statistik yang digunakan untuk menganalisa hubungan antara variabel respon dan variabel prediktor, dimana variabel respon bersifat polikotomus dengan skala ordinal [4]. Model yang digunakan untuk regresi logistik ordinal adalah model logit, dimana sifat yang tertuang dalam peluang kumulatif sehingga model logit kumulatif merupakan model yang didapatkan dengan cara membandingkan peluang kumulatif yaitu peluang kurang dari atau sama dengan kategori respon ke- $r$ pada $p$ variabel prediktor yang dinyatakan dalam vektor $x i$, dengan peluang lebih besar daripada ketegori respon ke- $r, \mathrm{P}(Y>r \mid x i)$ [5]. Peluang kumulatif $\mathrm{P}(Y \leq r \mid x i)$ didefinisikan sebagai berikut.

$$
P\left(Y \leq r \mid \mathbf{x}_{i}\right)=\frac{\exp \left(\beta_{0 r}+\sum_{k=1}^{p} \beta_{k} \mathbf{x}_{i k}\right)}{1+\exp \left(\beta_{0 r}+\sum_{k=1}^{p} \beta_{k} \mathbf{X}_{i k}\right)}
$$

dimana $\mathbf{x}_{i}=\left(\mathbf{x}_{i 1}, \mathbf{x}_{i 2}, \ldots, \mathbf{x}_{i p}\right)$ merupakan nilai pengamatan ke- $i$ $(i=1,2, \ldots, n)$ dari setiap variabel $p$ variabel prediktor. Pendugaan parameter regresi dilakukan dengan cara menguraikannya menjadi transformasi logit dari $\mathrm{P}\left(Y \leq r \mid \mathbf{x}_{i}\right)$.

$$
\begin{aligned}
\operatorname{Logit} P\left(Y \leq r \mid \mathbf{x}_{i}\right) & =\ln \left(\frac{P\left(Y \leq r \mid \mathbf{x}_{i}\right)}{1-P\left(Y \leq r \mid \mathbf{x}_{i}\right)}\right) \\
& =\beta_{0 r}+\sum_{k=1}^{p} \beta_{k} \mathbf{x}_{i k}
\end{aligned}
$$

dengan nilai $\beta_{k}$ untuk setiap $k=1,2, \ldots, p$ pada setiap model regresi logistik ordinal adalah sama. Jika terdapat kategori respon dimana $r=1,2,3,4$ maka peluang kumulatif dari respon ke-r seperti persamaan (4), (5), (6).

$$
\begin{aligned}
& P\left(Y \leq 1 \mid \mathbf{x}_{i}\right)=\frac{\exp \left(\beta_{01}+\sum_{k=1}^{p} \beta_{k} \mathbf{x}_{i k}\right)}{1+\exp \left(\beta_{01}+\sum_{k=1}^{p} \beta_{k} \mathbf{x}_{i k}\right)} \\
& P\left(Y \leq 2 \mid \mathbf{x}_{i}\right)=\frac{\exp \left(\beta_{02}+\sum_{k=1}^{p} \beta_{k} \mathbf{x}_{i k}\right)}{1+\exp \left(\beta_{02}+\sum_{k=1}^{p} \beta_{k} \mathbf{x}_{i k}\right)} \\
& P\left(Y \leq 3 \mid \mathbf{x}_{i}\right)=\frac{\exp \left(\beta_{03}+\sum_{k=1}^{p} \beta_{k} \mathbf{x}_{k i}\right)}{1+\exp \left(\beta_{03}+\sum_{k=1}^{p} \beta_{k} \mathbf{x}_{i k}\right)}
\end{aligned}
$$

Berdasarkan ketiga peluang kumulatif pada persamaan (4), (5), (6), didapatkan peluang untuk masing-masing kategori respon sebagai berikut.

$$
\begin{gathered}
P\left(Y=1 \mid \mathbf{x}_{i}\right)=\pi_{1}(x)=\frac{\exp \left(\beta_{01}+\sum_{k=1}^{p} \beta_{k} \mathbf{x}_{i k}\right)}{1+\exp \left(\beta_{01}+\sum_{k=1}^{p} \beta_{k} \mathbf{x}_{i k}\right)} \\
P\left(Y=2 \mid \mathbf{x}_{i}\right)=\pi_{2}(x)=\frac{\exp \left(\beta_{02}+\sum_{k=1}^{p} \beta_{k} \mathbf{x}_{k k}\right)}{1+\exp \left(\beta_{02}+\sum_{k=1}^{p} \beta_{k} \mathbf{x}_{i k}\right)}- \\
P\left(Y=3 \mid \mathbf{x}_{i}\right)=\pi_{3}(x)=\frac{\exp \left(\beta_{01}+\sum_{k=1}^{p} \beta_{k} \mathbf{x}_{i k}\right)}{1+\exp \left(\beta_{03}+\sum_{k=1}^{p} \beta_{k} \mathbf{x}_{k k}\right)}- \\
\frac{\exp \left(\beta_{02}+\sum_{k=1}^{p} \beta_{k} \mathbf{x}_{k i}\right)}{1+\exp \left(\beta_{02}+\sum_{k=1}^{p} \beta_{k} \mathbf{x}_{k k}\right)} \\
P\left(Y=3 \mid \mathbf{x}_{i}\right)=\pi_{4}(x)=1-\frac{\exp \left(\beta_{03}+\sum_{k=1}^{p} \beta_{k} \mathbf{x}_{i k}\right)}{1+\exp \left(\beta_{03}+\sum_{k=1}^{p} \beta_{k} \mathbf{x}_{i k}\right)}
\end{gathered}
$$

\section{Pengujian Estimasi Parameter}

Model yang telah diperoleh perlu diuji signifikansi pada koefisien $\beta$ terhadap variabel respon, yaitu dengan uji serentak dan uji parsial.

\section{1) Uji Serentak}

Pengujian ini digunakan untuk memeriksa signifikansi koefisien $\beta$ secara keseluruhan, dengan hipotesis:

$\mathrm{H}_{0}: \beta_{1}=\beta_{2}=\ldots=\beta_{p}=0$

$\mathrm{H}_{1}:$ minimal ada satu $\beta_{k} \neq 0, k=1,2, \ldots, p$

Statistik uji yang digunakan adalah statistik uji $G$ atau Likelihood Ratio Test pada persamaan (10).

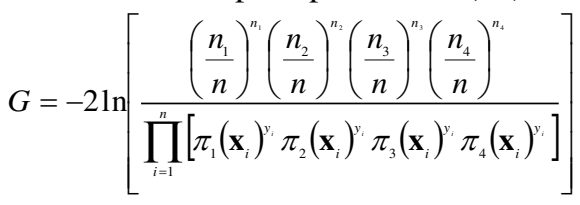

dimana, $n_{1}=\sum_{i=1}^{n} y_{1 i}, n_{2}=\sum_{i=1}^{n} y_{2 i}, n_{3}=\sum_{i=1}^{n} y_{3 i}, n_{4}=\sum_{i=1}^{n} y_{4 i}$, 
$n=n_{1}+n_{2}+n_{3}+n_{4}$. Statistik uji G mengikuti distribusi ChiSquare dengan derajat bebas $v$, sehinggav $\mathrm{H}_{0}$ ditolak jika $\mathrm{G}^{2}>$ $\chi_{(\alpha, v)}^{2}$ atau nilai $\mathrm{p}_{\text {value }}<\alpha$. [5].

2) Uji Parsial

Pengujian ini digunakan untuk memeriksa signifikansi koefisien $\beta$ secara parsial dengan hipotesis dan statistik uji:

$\mathrm{H}_{0}: \beta_{k}=0$

$\mathrm{H}_{1}: \beta_{\mathrm{k}} \neq 0, k=1,2, \ldots, p$

Statistik uji yang digunakan adalah statistik uji Wald.

$$
W=\frac{\hat{\beta}_{k}}{S E\left(\hat{\beta}_{k}\right)}
$$

Daerah penolakan $\mathrm{H}_{0}$ adalah $|\mathrm{W}|>Z_{\alpha / 2}$ atau $W^{2}>\chi_{(\mathrm{db}, \alpha)}^{2}$ dengan $d b$ adalah banyaknya variabel prediktor [5].

\section{E. PT. PLN Area Surabaya Selatan}

PT. PLN Area Surabaya Selatan merupakan salah satu unit PT. PLN (Persero) yang mempunyai tugas pokok mendistribusikan tenaga listrik ke pelanggan melalui jaringan tegangan menengah, serta melayani dan menyalurkan energi kepada pelanggan. Dalam sistem tegangan listrik tentu tidak terhindar dari suatu masalah kualitas tegangan maupun kontinuitas pelayanan. Hal ini terbukti dengan adanya keluhan terhadap gangguan listrik dari masyarakat. Setiap tahunnya PT. PLN Area Surabaya Selatan memiliki target gangguan listrik maksimal, yang harapannya banyak gangguan listrik berada dibawah target. Untuk mencapai target tersebut, diperlukan strategi untuk efisiensi penanganan gangguan. Berdasarkan hal tersebut PT. PLN (Persero) menetapkan kondisi jaringan yang dibagi menjadi 4 , dapat dilihat dalam Tabel 1.

Tabel 1.

Kondisi Jaringan

\begin{tabular}{cc}
\hline \hline Kondisi & Banyak Gangguan dalam 1 tahun \\
\hline Sempurna & 0 \\
Sehat & $1-2$ \\
Sakit & 3 \\
Kronis & $>3$ \\
\hline \hline
\end{tabular}

Penentuan kondisi jaringan dalam Tabel 1, ditentukan berdasarkan jumlah gangguan yang terjadi selama 1 tahun. Adapun indikator-indikator lain yang diduga berpengaruh dalam menentukan anggaran gangguan adalah.

1. Kelas Aset adalah penggolongan kelas aset distribusi yang didasarkan pada perbedaan daerah pelayanan. Kelas aset dibedakan menjadi 3, yaitu kelas 1 (kawasan industri), kelas 2 (perkotaan), kelas 3 (pedesaan). Aset trafo distribusi yang berada pada kelas aset yang berbeda akan mendapat frekuensi pemeliharaan terhadap trafo distribusi kelas 1 lebih sering/cepat dibandingkan kelas 2 dan 3 [6].

2. Pelanggan Tegangan Menengah adalah pengguna listrik yang berlangganan jaringan dengan tegangan menengah. Pelayanan yang diberikan pada jaringan tegangan menengah memilki beberapa unsur yaitu: Kontinuitas pelayanan, pengaturan tegangan dan tegangan kedip yang diizinkan.

3. Jumlah Pelanggan Tegangan Rendah adalah pengguna listrik yang berlangganan jaringan dengan tegangan rendah.
4. Panjang Jaringan Tegangan Menengah (JTM) memiliki satuan kilometer sirkuit (kms). Pajang JTM merupakan jarak dalam satu jaringan, dimana semakin panjang JTMnya biaya pemeliharaan yang dikeluarkan semakin besar jika terjadi gangguan.

5. Beban rata-rata adalah beban rata-rata pada suatu jaringan dengan satuan Ampere (A), dimana semakin beban ratarata suatu jaringan maka semakin tinggi tingkat prioritasnya.

\section{METODOLOGI PENELITIAN}

\section{A. Sumber Data}

Data yang digunakan dalam penelitian ini merupakan data sekunder diperoleh dari PT. PLN Area Surabaya Selatan yaitu data laporan gangguan jaringan PT. PLN Area Surabaya Selatan tahun 2016. PT. PLN Area Surabaya Selatan menaungi 157 jaringan dari 5 rayon, yaitu Darmo Permai, Dukuh Kupang, Gedangan, Ngagel, dan Rungkut. Variabel yang digunakan dalam penelitian ini berupa 1 variabel respon dan 5 variabel prediktor yang disajikan dalam Tabel 2 .

Tabel 2.

Variabel Penelitian

\begin{tabular}{clcc}
\hline \hline Simbol & \multicolumn{1}{c}{ Variabel } & Kategori & Ket. \\
\hline $\mathrm{Y}$ & Kondisi Jaringan & 1 & Sempurna \\
& & 2 & Sehat \\
& & 3 & Sakit \\
$\mathrm{X}_{1}$ & Kelas aset & 4 & Kronis \\
& & 1 & Industri \\
& & 2 & Perkotaan \\
$\mathrm{X}_{2}$ & Banyaknya pelanggan TM & 3 & Pedesaan \\
$\mathrm{X}_{3}$ & Banyaknya pelanggan TR & - & - \\
$\mathrm{X}_{4}$ & Panjang JTM (kms) & - & - \\
$\mathrm{X}_{5}$ & Beban rata-rata (A) & - & - \\
\hline \hline
\end{tabular}

\section{B. Langkah-Langkah Analisis Data}

Langkah analisis data yang dilakukan untuk menganalisis tingkat prioritas jaringan di PT. PLN Area Surabaya Selatan adalah sebagai berikut.

1. Mendeskripsikan karakteristik dari jaringan di PT. PLN Area Surabaya Selatan berdasarkan empat kategori dari variabel respon.

2. Membagi data menjadi dua, yaitu data training dan data testing masing-masing sebanyak $75 \%$ dan $25 \%$.

3. Melakukan pengelompokan menjadi dua kelompok terhadap data training, dengan menggunakan metode klaster non-hirarki (K-Means) berdasarkan variabel prediktor. Selanjutnya mendeskripsikan karakteristik dari masing-masing kelompok berdasarkan variabel prediktor.

4. Melakukan analisis regresi logistik ordinal di tiap kelompok untuk mengetahui indikator-indikator yang membedakan antar kelompok. Analisis regresi logistik ordinal terdiri dari beberapa tahapan analisis sebagai berikut:

a. Uji signifikansi parameter secara serentak dan parsial untuk mengetahui variabel prediktor yeng berpengaruh signifikan secara serentak dan individu terhadap model. 
b. Membuat model regresi logistik ordinal berdasarkan variabel-variabel yang signifikan pada pengujian estimasi parameter secara parsial.

5. Mengklasifikasikan data testing berdasarkan model regresi logistik ordinal.

\section{ANALISIS DAN PEMBAHASAN}

\section{A. Pengelompokan Jaringan PT. PLN Area Surabaya Selatan}

Karakteristik jaringan PT. PLN area Surabaya Selatan berdasarkan empat kategori kondisi jaringan tahun 2016 dapat dilihat dalam Gambar 1. Gambar 1 menunjukkan bahwa sebanyak 16,6\% dari 157 jaringan memiliki kondisi sempurna yaitu tidak terjadi gangguan, $28 \%$ dari 157 jaringan terjadi 1 dan 2 gangguan, 9,6\% jaringan terjadi 3 gangguan, dan $45,9 \%$ dari 157 jaringan terjadi gangguan lebih dari 3 gangguan selama tahun 2016. Kondisi jaringan yang telah ditetapkan PT. PLN selama ini masih belum tepat, karena hanya berdasar banyaknya gangguan di masing-masing jaringan. Oleh karena itu dilakukan pengelompokan jaringan dilakukan menggunakan analisis klaster K-Means. Pengelompokan dilakukan terhadap 120 data training, dan menghasilkan 44 jaringan masuk dalam kelompok 1, 76 jaringan masuk dalam kelompok 2.

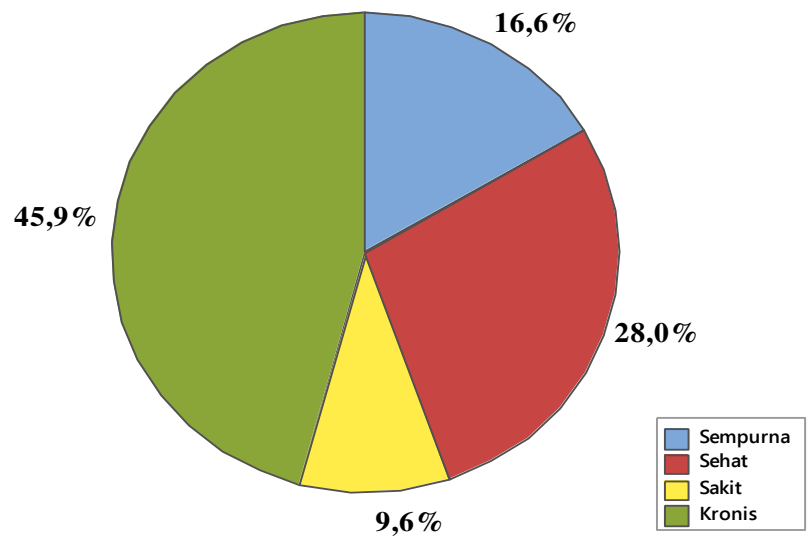

Gambar 1. Persentase kondisi jaringan.

Selanjutnya dilakukan analisis statistiska deskriptif yang ditampilkan dalam Tabel 3.

Tabel 3.

Karakteristik Kelompok 1 \& 2

\begin{tabular}{crrrrr}
\hline \hline Variabel & Kel. & \multicolumn{1}{c}{ Mean } & Std. Dev & \multicolumn{1}{c}{ Min } & \multicolumn{1}{c}{ Max } \\
\hline \multirow{2}{*}{$\mathrm{X}_{2}$} & 1 & 2,364 & 2,488 & 0 & 10 \\
& 2 & 3,592 & 4,828 & 0 & 27 \\
$\mathrm{X}_{3}$ & 1 & 7227 & 3070 & 1544 & 16922 \\
& 2 & 1576 & 1664 & 0 & 6667 \\
$\mathrm{X}_{4}$ & 1 & 14,886 & 4,293 & 9 & 26 \\
& 2 & 6,026 & 2,948 & 0 & 12 \\
$\mathrm{X}_{5}$ & 1 & 92,07 & 50,27 & 5 & 203 \\
& 2 & 91,62 & 46,53 & 3 & 201 \\
\hline \hline
\end{tabular}

Tabel 3 menunjukkan bahwa kelompok 1 memiliki rata-rata yang lebih tinggi daripada kelompok 1 berdasarkan pelanggan TR, panjang JTM, dan beban rata-rata. Sedangkan kelompok 2 memiliki rata-rata jumlah pelanggan TM lebih tinggi daripada kelompok 1, dengan jumlah pelanggan maksimum adalah sebanyak 27 pelanggan TM.

\section{B. Uji Multikolinearitas}

Pengujian multikolinearitas dilakukan untuk mengetahui ada atau tidaknya hubungan antar variabel prediktor dalam model regresi logistik ordinal. Multikolinearitas dapat diperiksa melalui nilai VIF yang disajikan dalam Tabel 4.

Tabel 4.

Nilai VIF Kelompok $1 \& 2$

\begin{tabular}{lcccc}
\hline \multirow{2}{*}{\multicolumn{1}{c}{ Variabel }} & \multicolumn{2}{c}{ Kelompok 1 } & \multicolumn{2}{c}{ Kelompok 2 } \\
\cline { 2 - 5 } & $\mathrm{R}^{2}$ & $\mathrm{VIF}$ & $\mathrm{R}^{2}$ & $\mathrm{VIF}$ \\
\hline Kelas Aset & 0,211 & 1,267 & 0,128 & 1,147 \\
Jumlah Pelanggan TM & 0,150 & 1,176 & 0,277 & 1,383 \\
Jumlah Pelanggan TR & 0,039 & 1,040 & 0,418 & 1,717 \\
Panjang JTM & 0,186 & 1,229 & 0,482 & 1,931 \\
Beban Rata-rata & 0,077 & 1,083 & 0,009 & 1,008 \\
\hline \hline
\end{tabular}

Tabel 4 menunjukkan bahwa masing-masing variabel prediktor memiliki nilai VIF lebih kecil dari 10. Sehingga dapat disimpulkan bahwa pada data kelompok 1 \& 2 tidak terjadi kasus multikolinearitas.

\section{Regresi Logistik Ordinal Kelompok 1}

Analisis regresi logistik ordinal yang pertama adalah melakukan uji signifikansi parameter secara serentak dengan hipotesis:

$\mathrm{H}_{0}: \beta_{1}=\beta_{2}=\beta_{3}=\beta_{4}=\beta_{5}=0$

$\mathrm{H}_{1}$ : minimal ada satu $\beta_{k} \neq 0, \mathrm{k}=1,2,3,4,5$

Pada taraf signifikansi 5\%, hasil uji signifikansi parameter secara serentak disajikan dalam Tabel 5.

Tabel 5

Uji Signifikansi Parameter Secara Serentak dari Kelompok 1

\begin{tabular}{lllll}
\hline \hline \multirow{2}{*}{ Model } & $\begin{array}{l}-2 \text { Log } \\
\text { Likelihood }\end{array}$ & Chi-Square & df & \multirow{2}{*}{ Keputusan } \\
\hline Intercept Only & 97,200 & & & \\
Final & 79,454 & 17,747 & 5 & Tolak H $_{0}$ \\
\hline \hline
\end{tabular}

Tabel 5 menunjukkan hasil pengujian secara serentak yang menghasilkan nilai $\mathrm{G}^{2}$ sebesar 79,454 yang artinya lebih besar dari $\chi^{2}{ }_{(0,05 ; 5)}=11,0705$, maka dapat diambil keputusan tolak $\mathrm{H}_{0}$. Sehingga dapat dikatakan paling sedikit ada satu variabel prediktor yang signifikan masuk kedalam model. Setelah dilakukan pengujian signifikansi parameter secara serentak, dilakukan pengujian parameter secara parsial dengan hipotesis:

$\mathrm{H}_{0}: \beta_{k}=0$

$\mathrm{H}_{1}: \beta_{k} \neq 0, \mathrm{k}=1,2,3,4,5$

Pada taraf signifikansi 5\%, berikut hasil uji signifikansi parameter secara parsial ditampilkan dalam Tabel 6.

Tabel 6.

Uji Signifikansi Parameter Secara Parsial dari Kelompok 1

\begin{tabular}{crrr}
\hline \hline Variabel & Koef $(\mathrm{B})$ & Wald & $\mathrm{P}_{\text {value }}$ \\
\hline $\mathrm{Y}(1)$ & 0,5807 & 0,104 & 0,747 \\
$\mathrm{Y}(2)$ & 3,2727 & 3,352 & 0,067 \\
$\mathrm{Y}(3)$ & 3,8450 & 4,478 & 0,034 \\
$\mathrm{Y}(4)$ & Pembanding & & \\
$\mathrm{X}_{1}(1)$ & 0,0469 & 0,004 & 0,951 \\
$\mathrm{X}_{1}(2)$ & Pembanding & & \\
$\mathrm{X}_{2}$ & $-0,0353$ & 0,058 & 0,809 \\
$\mathrm{X}_{3}$ & $-0,0001$ & 0,837 & 0,360 \\
$\mathrm{X}_{4}$ & 0,3708 & 8,364 & 0,004 \\
$\mathrm{X}_{5}$ & $-0,0064$ & 0,985 & 0,951 \\
\hline \hline
\end{tabular}


Berdasarkan Tabel 6 terlihat bahwa variabel prediktor panjang JTM berpengaruh secara signifikan terhadap kondisi jaringan dalam kelompok 1 . Selanjutnya adalah membentuk fungsi model logit.

Logit 1 (Sempurna)

$\left.g_{1}(x)=0,5807+0,0469\left(X_{1}\right)_{[1]}-0,0353\left(X_{2}\right)-0,000108 \$ X_{3}\right)+0,3708\left(X_{4}\right)-0,0064\left(X_{5}\right)$

Logit 2 (Sehat)

$g_{2}(x)=3,2727+0,0469\left(X_{1}\right)_{[1]}-0,0353\left(X_{2}\right)-0,000108 \$\left(X_{3}\right)+0,3708\left(X_{4}\right)-0,0064\left(X_{5}\right)$

Logit 3 (Sakit)

$\left.g_{3}(x)=3,8450+0,0469\left(X_{1}\right)_{[1]}-0,0353\left(X_{2}\right)-0,000108 \$ X_{3}\right)+0,3708\left(X_{4}\right)-0,0064\left(X_{5}\right)$

Model regresi logistik ordinal kelompok 1 memiliki nilai $R^{2}$ sebesar 0,373 atau sebesar $37,3 \%$. Artinya variabel kelas aset, jumlah pelanggan TM, jumlah pelanggan TR, panjang JTM, dan beban rata-rata mempengaruhi kondisi jaringan sebesar $37,3 \%$ sedangkan $62,7 \%$ dipengaruhi oleh faktor-faktor lainnya yang tidak termasuk dalam pengujian model.

\section{Regresi Logistik Ordinal Kelompok 2}

Analisis regresi logistik ordinal yang pertama pada dalam kelompok 2 juga dilakukan uji signifikansi parameter secara serentak dengan hipotesis:

$\mathrm{H}_{0}: \beta_{1}=\beta_{2}=\beta_{3}=\beta_{4}=\beta_{5}=0$

$\mathrm{H}_{1}$ : minimal ada satu $\beta_{k} \neq 0, \mathrm{k}=1,2,3,4,5$

Pada taraf signifikansi $5 \%$, hasil uji signifikansi parameter secara serentak disajikan dalam Tabel 7.

Tabel 7.

Uji Signifikansi Parameter Secara Serentak dari Kelompok 2

\begin{tabular}{|c|c|c|c|c|}
\hline Model & $\begin{array}{l}-2 \text { Log } \\
\text { Likelihood }\end{array}$ & Chi-Square & $\mathrm{df}$ & Keputusan \\
\hline Intercept Only & 198,149 & & & \\
\hline Final & 158,449 & 39,700 & 6 & Tolak $\mathrm{H}_{0}$ \\
\hline
\end{tabular}

Tabel 8.

Uji Signifikansi Parameter Secara Parsial dari Kelompok 2

\begin{tabular}{crcl}
\hline \hline Variabel & Koef $(\mathrm{B})$ & Wald & $\mathrm{P}_{\text {value }}$ \\
\hline $\mathrm{Y}(1)$ & 0,04787 & 0,001 & 0,976 \\
$\mathrm{Y}(2)$ & 2,09638 & 1,653 & 0,199 \\
$\mathrm{Y}(3)$ & 2,70959 & 2,725 & 0,099 \\
$\mathrm{Y}(4)$ & Pembanding & & \\
$\mathrm{X}_{1}(1)$ & $-0,51146$ & 0,126 & 0,723 \\
$\mathrm{X}_{1}(2)$ & $-0,18227$ & 0,016 & 0,899 \\
$\mathrm{X}_{1}(3)$ & Pembanding & & \\
$\mathrm{X}_{2}$ & 0,23652 & 7,589 & 0,006 \\
$\mathrm{X}_{3}$ & $-0,00001$ & 0,003 & 0,954 \\
$\mathrm{X}_{4}$ & 0,35603 & 9,234 & 0,002 \\
$\mathrm{X}_{5}$ & $-0,00762$ & 2,271 & 0,132 \\
\hline \hline
\end{tabular}

Tabel 7 menunjukkan hasil pengujian secara serentak yang menghasilkan nilai $\mathrm{G}^{2}$ sebesar 158,449 yang artinya lebih besar dari $\chi_{(0,05 ; 6)}^{2}=12,591$, maka dapat diambil keputusan tolak $\mathrm{H}_{0}$. Sehingga dapat dikatakan paling sedikit ada satu variabel prediktor yang signifikan masuk kedalam model. Setelah dilakukan pengujian signifikansi parameter secara serentak, dilakukan pengujian parameter secara parsial dengan hipotesis:

$\mathrm{H}_{0}: \beta_{k}=0$

$\mathrm{H}_{1}: \beta_{k} \neq 0, \mathrm{k}=1,2,3,4,5$

Pada taraf signifikansi $5 \%$, berikut hasil uji signifikansi parameter secara parsial ditampilkan dalam Tabel 8.

Berdasarkan Tabel 8 terlihat bahwa variabel prediktor jumlah pelanggan TM dan panjang JTM berpengaruh secara signifikan terhadap kondisi jaringan dalam kelompok 1 . Selanjutnya adalah membentuk fungsi model logit.

Logit 1 (Sempurna)

$$
\begin{aligned}
g_{1}(x) & \left.=0,048-0,511\left(X_{1}\right)_{\mid 11}-0,182\left(X_{1}\right)_{\mid 21}+0,237\left(X_{2}\right)-0,000010 \$ X_{3}\right) \\
& +0,356\left(X_{4}\right)-0,008\left(X_{5}\right)
\end{aligned}
$$

Logit 2 (Sehat) $\begin{aligned} g_{2}(x) & \left.=2,096-0,511\left(X_{1}\right)_{111}-0,182\left(X_{1}\right)_{121}+0,237\left(X_{2}\right)-0,000010 k X_{3}\right) \\ & +0,356\left(X_{4}\right)-0,008\left(X_{5}\right)\end{aligned}$

Logit 3 (Sakit)

$g_{3}(x)=2,71-0,511\left(X_{1}\right)_{111}-0,182\left(X_{1}\right)_{k 21}+0,237\left(X_{2}\right)-0,000010\left(X_{3}\right)$ $+0,356\left(X_{4}\right)-0,008\left(X_{5}\right)$

Model regresi logistik ordinal kelompok 2 memiliki nilai $R^{2}$ sebesar 0,439 atau sebesar $43,9 \%$. Artinya variabel kelas aset, jumlah pelanggan TM, jumlah pelanggan TR, panjang JTM, dan beban rata-rata mempengaruhi kondisi jaringan sebesar $43,9 \%$ sedangkan $56,1 \%$ dipengaruhi oleh faktor-faktor lainnya yang tidak termasuk dalam pengujian model.

\section{E. Variabel Pembeda Kelompok 1 dan Kelompok 2}

Tabel 9.

\begin{tabular}{|c|c|c|c|c|}
\hline No. & Jaringan & Rayon & $\overline{\mathrm{X}_{4}}$ & Kelompok \\
\hline 1 & Alas Malang & Darmo Permai & 2 & 2 \\
\hline 2 & Darmo Harapan & Darmo Permai & 7 & 2 \\
\hline 3 & Darmo Permai & Darmo Permai & 16 & 1 \\
\hline 4 & Lidah Kulon & Darmo Permai & 13 & 1 \\
\hline 5 & Puncak Permai & Darmo Permai & 14 & 1 \\
\hline 6 & Suko Manunggal & Darmo Permai & 12 & 1 \\
\hline 7 & Villa Bukit Regency & Darmo Permai & 5 & 2 \\
\hline 8 & Water Place 1 & Darmo Permai & 1 & 2 \\
\hline 9 & Brawijaya & Dukuh Kupang & 10 & 1 \\
\hline 10 & Diponegoro & Dukuh Kupang & 13 & 1 \\
\hline 11 & Graha Pena & Dukuh Kupang & 7 & 2 \\
\hline 12 & Menanggal & Dukuh Kupang & 9 & 2 \\
\hline 13 & Simo Gunung & Dukuh Kupang & 3 & 2 \\
\hline 14 & Simo Kwagean & Dukuh Kupang & 8 & 2 \\
\hline 15 & Delta Sari & Gedangan & 15 & 1 \\
\hline 16 & Gms & Gedangan & 14 & 1 \\
\hline 17 & Pabean 1 & Gedangan & 9 & 2 \\
\hline 18 & Pabean 2 & Gedangan & 7 & 2 \\
\hline 19 & Sawo Tratap & Gedangan & 13 & 1 \\
\hline 20 & Trias 1 & Gedangan & 6 & 2 \\
\hline 21 & Bagong/Lumumba & Ngagel & 6 & 2 \\
\hline 22 & Barata & Ngagel & 5 & 2 \\
\hline 23 & Dokter Sutomo & Ngagel & 2 & 2 \\
\hline 24 & Krukah & Ngagel & 6 & 2 \\
\hline 25 & Nias & Ngagel & 7 & 2 \\
\hline 26 & Pucang Adi & Ngagel & 4 & 2 \\
\hline 27 & Ratna & Ngagel & 4 & 2 \\
\hline 28 & Sulawesi & Ngagel & 7 & 2 \\
\hline 29 & Bandilan & Rungkut & 8 & 2 \\
\hline 30 & Kalisco & Rungkut & 7 & 2 \\
\hline 31 & Mangga Dua & Rungkut & 8 & 2 \\
\hline 32 & Nirwana & Rungkut & 6 & 2 \\
\hline 33 & Pondok Candra & Rungkut & 18 & 1 \\
\hline 34 & Rsal & Rungkut & 9 & 2 \\
\hline 35 & Siwalan Kerto & Rungkut & 8 & 2 \\
\hline 36 & Wonokromo & Rungkut & 1 & 2 \\
\hline 37 & Zamhuri & Rungkut & 15 & 1 \\
\hline
\end{tabular}

Penentuan Kelompok Data Testing

Berdasarkan hasil analisis regresi logistik ordinal yang telah dilakukan, variabel yang signifikan dalam kelompok 1 adalah variabel panjang JTM. Sedangkan variabel yang signifikan dalam kelompok 2 adalah variabel jumlah pelanggan TM dan panjang JTM. Sehingga variabel pembeda antara kelompok 1 dan kelompok 2 adalah variabel panjang JTM. Berdasarkan karakteristik variabel jumlah pelanggan TM dan panjang JTM 
pada Tabel 3, dapat diketahui bahwa kelompok 1 memiliki panjang JTM yang lebih panjang dan jumlah pelanggan TM lebih sedikit dibanding kelompok 2. Penentuan kelompok data testing ditampilkan dalam Tabel 9.

Selanjutnya data setiap kelompok dimasukkan ke dalam model logit hasil regresi logistik ordinal. Model logit hasil regresi logistik ordinal kelompok 1 dan kelompok 2 dapat digunakan untuk memprediksi kondisi jaringan. Hasil prediksi kelompok 1 ditampilkan dalam Tabel 10.

Tabel 10 .

Prediksi Data Testing Kelompok 1

\begin{tabular}{cccccc}
\hline \hline No. & $\pi_{1}$ & $\pi_{2}$ & $\pi_{3}$ & $\pi_{4}$ & Prediksi \\
\hline 3 & 0,0238 & 0,3282 & 0,2719 & 0,3761 & Kronis \\
4 & 0,0238 & 0,3282 & 0,2719 & 0,3761 & Kronis \\
5 & 0,0238 & 0,3281 & 0,2718 & 0,3762 & Kronis \\
6 & 0,0238 & 0,3281 & 0,2718 & 0,3763 & Kronis \\
9 & 0,0238 & 0,3276 & 0,2714 & 0,3773 & Kronis \\
10 & 0,0238 & 0,3282 & 0,2718 & 0,3762 & Kronis \\
15 & 0,0238 & 0,3282 & 0,2718 & 0,3762 & Kronis \\
16 & 0,0238 & 0,3281 & 0,2718 & 0,3762 & Kronis \\
19 & 0,0238 & 0,3281 & 0,2718 & 0,3762 & Kronis \\
33 & 0,0239 & 0,3282 & 0,2719 & 0,3760 & Kronis \\
37 & 0,0238 & 0,3282 & 0,2719 & 0,3761 & Kronis \\
\hline \hline
\end{tabular}

Berdasarkan data testing kelompok 1 dapat dilakukan pengklasifikasian dengan cara memasukkan data tiap jaringan Lampiran 1, ke dalam model peluang yang telah terbentuk sehingga diperoleh nilai peluang dan prediksi kondisi jaringan untuk masing-masing jaringan. Jaringan ketiga merupakan jaringan Darmo Permai dengan karakteristik kelas 1, jumlah pelanggan TM 2, jumlah pelanggan TR 4121, panjang JTM 16 $\mathrm{kms}$, dan memiliki beban rata-rata 191A. Selanjutnya karakteristik tersebut dimasukkan ke dalam model peluang yang telah diperoleh, sehingga diperoleh nilai peluang dari 4 kategori masing-masing adalah $0,0238,0,3282,0,2719$, dan 0,3761 .

Berdasarkan karakteristik kondisi jaringan dalam Gambar 1 jumlah persentase kondisi jaringan sempurna $(16,6 \%)$, sehat (28\%), dan sakit $(9,6 \%)$ adalah $54,2 \%$. Apabila jumlah peluang pertama hingga ketinga pada Tabel 9 lebih dari 0,542, maka sebuah jaringan tersebut diprediksi memiliki kondisi jaringan kronis. Kategori 4 adalah kondisi yang paling mungkin terjadi untuk jaringan Darmo Permai, dengan jumlah peluang pertama hingga ketiga 0,6239 yang lebih besar dari 0,542. Sehingga, jaringan Darmo Permai diprediksi akan memiliki kondisi jaringan kronis. Hasil prediksi kelompok 2 ditampilkan dalam Tabel 11.

Berdasarkan data testing kelompok 2, dapat dilakukan pengklasifikasian dengan cara memasukkan data tiap jaringan ke dalam model peluang yang telah terbentuk sehingga diperoleh nilai peluang dan prediksi kondisi jaringan untuk masing-masing jaringan. Jaringan pertama merupakan jaringan Alas Malang dengan karakteristik kelas 1, tidak memiliki pelanggan TM, 845 pelanggan TR, panjang JTM 2 $\mathrm{kms}$, dan beban rata-rata 130A. Selanjutnya karakteristik tersebut dimasukkan ke dalam model peluang yang telah diperoleh, sehingga diperoleh nilai peluang dari 4 kategori masing-masing adalah 0,0396, 0,2674, 0,2598, dan 0,4333. Apabila jumlah peluang pertama hingga ketiga pada Tabel 10 lebih dari 0,542, maka sebuah jaringan tersebut diprediksi memiliki kondisi jaringan kronis. Kategori 4 adalah kondisi yang paling mungkin terjadi untuk jaringan Alas Malang, dengan jumlah peluang 0,5667. Sehingga, jaringan Alas Malang diprediksi akan memiliki kondisi jaringan kronis.

Tabel 11.

Prediksi Data Testing Kelompok 2

\begin{tabular}{cccccc}
\hline \hline No. & $\pi_{1}$ & $\pi_{2}$ & $\pi_{3}$ & $\pi_{4}$ & Prediksi \\
\hline 1 & 0,0396 & 0,2674 & 0,2598 & 0,4333 & Kronis \\
2 & 0,0430 & 0,2908 & 0,2825 & 0,3837 & Kronis \\
7 & 0,0426 & 0,2880 & 0,2798 & 0,3896 & Kronis \\
8 & 0,0391 & 0,2639 & 0,2564 & 0,4406 & Kronis \\
11 & 0,0430 & 0,2903 & 0,2820 & 0,3848 & Kronis \\
12 & 0,0431 & 0,2913 & 0,2830 & 0,3826 & Kronis \\
13 & 0,0420 & 0,2836 & 0,2756 & 0,3988 & Kronis \\
14 & 0,0430 & 0,2905 & 0,2823 & 0,3842 & Kronis \\
17 & 0,0432 & 0,2917 & 0,2834 & 0,3818 & Kronis \\
18 & 0,0427 & 0,2888 & 0,2806 & 0,3879 & Kronis \\
20 & 0,0430 & 0,2903 & 0,2820 & 0,3847 & Kronis \\
21 & 0,0431 & 0,2909 & 0,2826 & 0,3834 & Kronis \\
22 & 0,0430 & 0,2905 & 0,2822 & 0,3843 & Kronis \\
23 & 0,0397 & 0,2682 & 0,2606 & 0,4315 & Kronis \\
24 & 0,0427 & 0,2884 & 0,2802 & 0,3886 & Kronis \\
25 & 0,0432 & 0,2918 & 0,2835 & 0,3815 & Kronis \\
26 & 0,0419 & 0,2832 & 0,2752 & 0,3997 & Kronis \\
27 & 0,0425 & 0,2869 & 0,2787 & 0,3919 & Kronis \\
28 & 0,0431 & 0,2915 & 0,2832 & 0,3822 & Kronis \\
29 & 0,0431 & 0,2913 & 0,2831 & 0,3825 & Kronis \\
30 & 0,0431 & 0,2914 & 0,2832 & 0,3823 & Kronis \\
31 & 0,0433 & 0,2925 & 0,2842 & 0,3799 & Kronis \\
32 & 0,0431 & 0,2913 & 0,2830 & 0,3826 & Kronis \\
34 & 0,0432 & 0,2919 & 0,2836 & 0,3812 & Kronis \\
35 & 0,0429 & 0,2900 & 0,2818 & 0,3852 & Kronis \\
36 & 0,0396 & 0,2677 & 0,2601 & 0,4326 & Kronis \\
\hline \hline & & & & & \\
\hline
\end{tabular}

\section{KESIMPULAN DAN SARAN}

Hasil pengelompokan dengan analisis klaster K-Means diperoleh kelompok 1 sebanyak 44 jaringan, sedangkan kelompok 2 sebanyak 76 jaringan. Kelompok 1 memiliki ratarata yang lebih tinggi daripada kelompok 2 berdasarkan pelanggan TR, panjang JTM, dan beban rata-rata. Sedangkan kelompok 2 memiliki rata-rata jumlah pelanggan TM lebih tinggi daripada kelompok 1. Hasil analisis regresi logistik ordinal, variabel pembeda antara kelompok 1 dan kelompok 2 adalah panjang JTM. Saran yang diberikan untuk PT. PLN Area Surabaya Selatan adalah lebih memperhatikan panjang JTM sebagai strategi efisiensi penanganan ketika ada gangguan. Kelompok 1 menjadi prioritas utama dan membutuhkan anggaran lebih banyak dibanding kelompok 2 karena memiliki panjang JTM yang lebih panjang. Saran untuk penelitian selanjutnya adalah perlu adanya penambahan variabel lain agar menghasilkan model yang lebih baik.

\section{DAFTAR PUSTAKA}

[1] N. D. Wahyuni, "13,1 Juta Pelanggan Listrik Pra Bayar RI Terbesar di Dunia, Bisnis," 2014. .

[2] Setiawan and D. Kusrini Endah, Ekonometrika. Yogyakarta: Andi, 2010. 
[3] R. A. Johnson and D. W. Wichern, Applied Multivariate Statistical Analysis, 6th ed. Pearson Education, Inc, 2007.

[4] D. Hosmer and S. Lemeshow, Applied Logistic Regressi, 2nd ed. New Jersey: Person Prentice Hall, 2007.

[5] A. Agresti, Categorical Data Analysis, 2nd ed. New York: John Wiley \&
Sons, Inc, 2002.

[6] PT. PLN. (Persero), "Metode Pemeliharaan Trafo Distribusi berdasarkan Kaidah Manajemen Aset," 0017.E/DIR/2014, 2014. 